\title{
Penerapan Model Problem Based Learning dengan Media Moodle dan Pengaruhnya terhadap Motivasi dan Hasil Belajar Kognitif Siswa
}

\author{
Lia Damayanti ${ }^{1 *}$, Lambang Subagiyo², Muliati Syam ${ }^{3}$ \\ 1,2,3 Program Studi Pendidikan Fisika, Fakultas Keguruan dan IImu Pendidikan \\ Universitas Mulawarman, Samarinda - Indonesia \\ `E-mail Penulis Korespondensi: Ihyamharina@gmail.com
}

\begin{abstract}
Abstrak
Penelitian ini berfokus pada model Problem Based Learning berbantuan Moodle yang bertujuan untuk mengetahui motivasi dan hasil belajar kognitif siswa. Jenis penelitian yang digunakan adalah penelitian deskriptif dengan one group pretest-postest. Pengambilan sampel dilakukan dengan cara purposive sampling dengan melibatkan 36 siswa. Pengumpulan data menggunakan angket motivasi belajar dan tes soal. Berdasarkan hasil analisis motivasi belajar didapati 3\% siswa berada pada kategori sangat rendah, $33 \%$ pada kategori rendah, $56 \%$ pada kategori cukup, dan $8 \%$ pada kategori tinggi dan analisis hasil belajar diperoleh ratarata nilai pre-test sebesar 56.71 dan rata-rata nilai post-test sebesar 78.5 , dari hasil tersebut diketahui peningkatan $\mathrm{N}$-Gain sebesar 0.503 yang masuk dalam kategori sedang. Untuk mengetahui keefektifan mode yang digunakan maka dihitung dengan uji wilcoxon dan didapati hasil Z Zitung (5.094) > dari Z tabel (2.892).

Kata kunci: Model Problem Based Learning, Moodle, Motivasi Belajar Siswa, Hasil Belajar Kognitif Siswa
\end{abstract}

\section{Abstract}

This research focuses on the Problem Based Learning model assisted by Moodle, which aims to determine students' motivation and cognitive learning outcomes. The type of research used is descriptive research with one group pretest-postest. The sampling technic was purposive sampling involving 36 students. Data collection using a learning motivation questionnaire and test questions. Based on the analysis of learning motivation, it was found that $3 \%$ of students were in the very low category, $33 \%$ in the low category, $56 \%$ in the medium category, and $8 \%$ in the high category. The analysis of learning outcomes obtained by the average pre-test score was 56.71, and the average post-test score was 78.5. From these results, it was known that the N-Gain increase was 0.503, which was in the medium category. The Wilcoxon test was used to determine the effectiveness of the model, and the result was $Z_{\text {count }}(5.094)>Z_{\text {table }}$ (2.892).

Keywords: Problem Based Learning, Moodle, Cognitive Learning Outcomes and Student Motivation

Article History: Received: 6 November 2020 Accepted: 25 Maret 2021

\section{Revised : 30 Maret 2021}

Published: 30 April 2021

How to cite: Damayanti, L., Subagyo, L., \& Syam, M., (2021). Penerapan Model Problem Based Learning dengan Media Moodle dan Pengaruhnya terhadap Motivasi dan Hasil Belajar Kognitif Siswa. Jurnal Literasi Pendidikan Fisika, 2(1). pp. 53-62. Retrieved from https://jurnal.fkip.unmul.ac.id/index.php/JLPF/

Copyright @ April 2021, Jurnal Literasi Pendidikan Fisika 
Pengaruh Model Pembelajaran...

\section{PENDAHULUAN}

Proses pembelajaran merupakan proses interaksi antara guru dan siswa. Proses pembelajaran antara guru dan siswa menjadi tolak ukur dalam meningkatkan kualitas belajar siswa. Kualitas belajar siswa akan meningkat apabila pendidik mampu meningkatkan kualitas belajar siswa dengan meningkatkan aktivitas, kreativitas, disiplin dan motivasi belajar siswa (Rahmawati, 2018). Hal ini menunjukkan bahwa guru memiliki peran yang sangat penting dalam menyajikan pembelajaran dan menjadi titik kritis bagi keberhasilan siswa dalam memahami dan menganalisis dari materi yang dipelajari. Hal ini dilakukan agar proses pembelajaran didalam kelas tidak membosankan sehingga membuat siswa menjadi cepat mengantuk dan lelah (Novianto, 2016). Cara mengajar yang masih terpusat pada guru membuat siswa kurang aktif dalam proses belajar. Kurang aktifnya siswa dalam pembelajaran menandakan bahwa motivasi belajar siswa akan sangat minim dengan model pembelajaran yang masih terpusat oleh guru. Hal ini tentunya membuat guru harus memiliki inovasi dengan mengubah gaya mengajar agar bisa meningkatkan motivasi belajar siswa.

Motivasi merupakan kekuatan dahsyat dayang dimiliki seseorang untuk menggapai kesuksesan (Sutikno, 2013). Motivasi akan timbul karena adanya hasrat dan keinginan berhasil dan dorongan kebutuhan belajar harapan akan cita-cita. Adanya motivasi akan memberikan dorongan manusia untuk berbuat. Jika motivasi dalam diri individu besar maka ia akan melakukan sesuatu karena keinginannya sendiri (Oemar Malik dalam Sutikno, 2013). Motivasi yang dimiliki siswa akan menentukan arah perbuatan siswa. Jika siswa memiliki motivasi belajar yang tinggi maka ia akan melakukan apapun dalam mencapai tujuannya, artinya motivasi memiliki pengaruh yang kuat karena berfungsi sebagai pendorong, pengarah sekaligus penggerak perilaku seseorang. Motivasi dapat timbul dari dalam diri individu (motivasi instrinsik) dan dari luar individu atau motivasi ekstrinsik (Susanti, 2014). Motivasi instrinsik adalah motivasi yang ada didalam diri individu tanpa harus dipengaruhi oleh orang lain atau lingkungan. Ketika seseorang memiliki motivasi instrinsik yang kuat maka tanpa dipengaruhi oleh apapun ia akan mampu melakukannya. Misalnya saja, seseorang saat membaca buku. Ketika seseorang memiliki kegemaran membaca maka tanpa mendapat perintah dari guru atau orang lain ia akan membaca buku tersebut (Sadirman, 2011). Motivasi ini lebih kuat dalam melakukan sesuatu hal. Lain halnya dengan motivasi ekstrinsik, ialah motivasi yang berasal dari luar individu. Motivasi ini harus memiliki dorongan yang kuat dari luar individu. Cara mengajar yang dilakukan oleh guru termasuk dalam motivasi ekstrinsik yaitu dorongan yang diberikan dari luar individu. Tentunya dari motivasi ekstrinsik ini diharapkan mampu meningkatkan motivasi instrinsik dalam diri siswa. Pentingnya meningkatkan motivasi belajar siswa juga memiliki pengaruh terhadap hasil belajar siswa. Motivasi belajar juga mempengaruhi hasil belajar kognitif siswa. Hal ini telah dibuktikan oleh Manggabarani, Sugiarti dan Masri (2016) dalam penelitian sebelumnya.

Hasil belajar adalah terjadinya perubahan tingkah laku pada diri peserta didik yang dapat diamati, dapat diukur dalam bentuk perubahan sikap dan keterampilan (Hamalik, 2001). Hasil belajar sering kali digunakan untuk mengevaluasi seberapa jauh siswa dalam menguasai bahan yang diajarkan melalui intrumen penilaian yang akurat serta memenuhi syarat (Sukri \& Purwanti, 2019). Hasil belajar siswa terbagi menjadi tiga ranah yaitu ranah kognitif, ranah afektif dan ranah psikomotorik.

Ranah kognitif, ranah ini berkenaan dengan ilmu pengetahuan siswa. Dalam ranah kognitif terdiri dari enam tingkatan. Tingkatan pertama ialah mengenal. Pada tingkatan ini siswa diminta untuk mengenal dan mengingat kembali fakta-fakta yang sederhana, seperti fungsi akar pada tumbuhan ialah untuk mengangkut air dari dalam tanah untuk disebarkan ke seluruh tubuh tumbuhan. Tingkatan kedua ialah memahami. Pada tingkatan ini siswa diminta untuk memahami hubungan yang sederhana dalam fakta-fakta. Ketiga ialah menerapkan. Siswa dituntut untuk memiliki kemampuan menyeleksi atau memilih suatu ide untuk diterapkan. Keempat analisis, yaitu untuk menganalisis suatu hubungan yang kompleks atau konsep-konsep dasar. Kelima, sintesis, dimana siswa diminta untuk membuat generalisasi. Keenam ialah evaluasi, yaitu penilain akhir setelah semua tingkatan ini

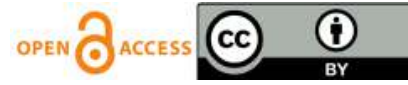


Pengaruh Model Pembelajaran...

diterapkan.

Ranah afektif ialah ranah dimana siswa diminta untuk mengeanai responsnya yang melibatkan sikap atau nilai. Ranah ini berhubungan dengan pandangan siswa yang melibatkan ekspresi, perasaan dan tahu pendapat pribadi siswa terhadap hal-hal yang bersifat sederhana tetapi bukan fakta. Ranah psikomotorik ialah ranah dimana siswa menggunakan kerja otot, artinya siswa diminta melakukan suatu hal yang dari yang sederhana seperti melipat kertas sampai dengan merakit suku cadang televisi serta komputer. Secara mendasar dapat dibedakan antara dua hal yaitu keterampilan dan kemampuan (Arikunto, 2007).

Pada penelitian ini yang menjadi perhatian bagi guru adalah ranah kognitif. Guru ingin mengetahui perubahan siswa dalam aspek pengetahuan. Dalam meningkatkan motivasi dan hasil belajar kognitif siswa tentunya perlu memperhatikan proses belajar mengajar didalam kelas. Siswa harus menjadi partisipan aktif agar dapat meningkatkan pengetahuan siswa sehingga perlunya model pembelajaran yang dapat melibatkan siswa dalam pembelajaran. Oleh karena itu, dalam peneltian ini peneliti menggunakan model problem based learning. Model pembelajaran ini mampu melibatkan siswa dalam suatu pembelajaran yang menjadikan masalah sebagai alternatif dalam mengembangkan keterampilan berfikir siswa (Rusman, 2011). Selain itu, model ini juga dapat membantu siswa dalam meningkatkan kerja tim dalam menyelesaian masalah, meningkatkan pengetahuan yang lebih relevan, mendorong siswa untuk berfikir serta realistik dengan kehidupan peserta (lqbal, Subchan dan Magfiroh, 2016). Masalah yang diberikan dalam penerapan model ini menjadi sangat penting agar dapat memberikan kesempatan kepada siswa untuk memperluas pengetahuan mereka dan merangsang cara berfikir siswa untuk memecahkan masalah (Priansyah, 2015).

Ada beberapa karakteristik dalam problem based learning yaitu dimulai dari suatu masalah. Selain itu juga memastikan masalah yang diberikan berhubungan dengan dunia nyata siswa, mengorganisasi pelajaran diseputar masalah, memberikan tanggung jawab yang besar kepada pembelajar dalam menjalankan proses belajar mereka sendiri, menggunakan kelompok kecil dan menuntut pembelajar untuk mendemonstrasikan apa yang telah mereka kerjakan (Fathurrohman, 2016). Siswa perlu dikembangkan pemikirannya karena setiap orang senantiasa dihadapkan pada berbagai masalah dan ragam pilihan sehingga untuk itu dituntut memiliki kemampuan berfikir yang kreatif dan kritis. Kreativitas juga menjadi aspek penting dalam memecahkan masalah mulai dari apa masalahnya, mengapa muncul masalah dan bagaimana cara pemecahannya.

Selama pembelajaran berlangsung juga diperlukan inovasi baru agar siswa tertarik dengan pembelajaran fisika. Salah satunya ialah penggunaan teknologi dalam proses pembelajaran. Penggunaan gadjet dapat dimanfaatkan dalam pembelajaran fisika. Salah satunya ialah penggunaan e-learning. Pembelajaran melalui e-learning bersifat fleksibel yang memungkinkan pengguna elearning dapat mengakses tanpa dibatasi oleh waktu dan tempat. Salah satu e-learning yang digunakan dalam penelitian ini adalah moodle. Moodle adalah e-learning yang dapat merubah sebuah media pembelajaran kedalam bentuk web. Moodle dapat mengakses materi-materi pembelajaran secara online (Muazizah, 2016). Moodle berguna untuk membuat dan mengadakan pembelajaran secara online (Abadi, 2017).

Model problem based learning berbantuan moodle ini diharapkan mampu menciptakan pembelajaran yang interaktif antara siswa dan guru. Model pembelajaran interaktif adalah suatu cara atau teknik pembelajaran yang digunakan oleh pendidik dalam menciptakan situasi interaktif dan edukatif untuk menunjang tercapainya tujuan belajar (Komara, 2014). Model pembelajaran dapat dikatakan model pembelajaran interaktif jika dapat membangkitkan motivasi, minat atau gairah belajar peserta didik. Selain itu, siswa juga diberikan kesempatan dalam memberikan tanggapan terakit materi yang telah disampaikan dan juga mendidik siswa dalam teknik belajar sendiri serta cara memperoleh pengetahuan melalui usaha sendiri. Oleh karena itu, penggabungan antara model problem based learning dan e-learning moodle diharapkan mampu meningkatkan motivasi dan hasil belajar siswa.

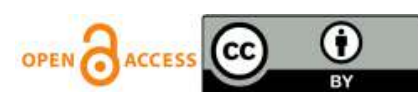


Pengaruh Model Pembelajaran...

\section{METODE}

Penelitian ini dilakukan pada bulan Oktober 2019 tepatnya di SMA Negeri 5 Samarinda dikelas XI. Sampel dalam penelitian ini adalah siswa kelas XI IPA 5 dengan jumlah 36 siswa. Pengambilan sampel dilakukan dengan teknik purposive sampling yaitu teknik pengambilan sumber data dengan pertimbangan tertentu (Sugiono, 2015). Penelitian menggunakan penelitian deskriptif untuk menjelaskan motivasi belajar siswa dan peningkatan hasil belajar kognitif siswa setelah diterapkan model Problem Based Learning berbantuan Moodle. Selain itu, penelitian ini juga menggunakan desain one-group pretest-posttest agar mengetahui hasil perlakuan dengan lebih akurat. Dengan desain ini, peneliti dapat membandingkan dengan keadaan sebelum setelah diberikan perlakuan. Desain ini dapat digambarkan sebagai berikut.

Tabel 1. Desain Penelitian

\begin{tabular}{ccc}
\hline Pre-Test & Treatment & Post Test \\
\hline$O_{1}$ & $\mathrm{X}$ & $\boldsymbol{O}_{2}$ \\
\hline
\end{tabular}

$\mathrm{O}_{1}=$ Nilai Pre Test (sebelum diberi perlakuan )

$\mathrm{O}_{2}=$ Nilai Post Test (setelah diberi perlakuan )

$\mathrm{X}=$ Perlakuan yang diberikan oleh model problem based learning berbantuan moodle.

Dalam penelitian ini digunakan angket dan tes tertulis sebagai instrumen penilaian untuk mengetahui motivasi dan hasil belajar kognitif siswa. Angket adalah pertanyaan-pertanyaan yang diberikan kepada siswa untuk mengetahui informasi dari dalam diri siswa. Angket ini digunakan untuk mengetahui seberapa besar motivasi siswa dalam mengikuti pembelajaran fisika. Angket yang diberikan sebanyak 15 butir pernyataan. Untuk mengetahui motivasi belajar siswa digunakan rumus sebagai berikut.

$$
P=\frac{F}{A} \times 100 \%
$$

\section{Dimana:}

$\mathrm{P}=$ presentase motivasi belajar

$F=$ jumlah skor perolehan

$A=$ jumlah skor maksimal

Dengan kriteria presentase motivasi belajar pada tabel berikut ini.

Tabel 2. Kriteria Presentase Motivasi Belajar

\begin{tabular}{ccc}
\hline No. & Tingkat Keberhasilan (\%) & Kategori \\
\hline 1. & $90-100$ & Sangat Tinggi \\
\hline 2. & $75-89$ & Tinggi \\
\hline 3. & $55-74$ & Cukup \\
\hline 4. & $40-54$ & Rendah \\
\hline 5. & $0-39$ & Sangat Rendah \\
\hline
\end{tabular}

Sedangkan untuk mengetahui peningkatan hasil belajar kognitif siswa menggunakan tes tertulis dengan 15 butir pertanyaan. Teknik analisis data yang digunakan dalam penelitian ini adalah N-Gain, untuk mengukur peningkatan hasil belajar kognitif siswa sebelum dan setelah diterapkan model problem based learning berbantuan moodle. Adapun rumus yang digunakan dalam N-Gain:

$$
N-\text { Gain }=\frac{\text { skorposttest-skorpretest }}{\text { skormaksimal-skorpretest }}
$$

Dengan kriteria N-Gain dapat dilihat pada tabel berikut. 
Pengaruh Model Pembelajaran...

Tabel 3. Kriteria N-Gain

\begin{tabular}{cc}
\hline Rentang & Kategori \\
\hline $\mathrm{N}-\mathrm{G} \geq 0.7$ & Tinggi \\
\hline $0.3 \leq \mathrm{N}-\mathrm{G} \leq 0.7$ & Sedang \\
\hline $\mathrm{N}-\mathrm{G}<0.3$ & Rendah \\
\hline
\end{tabular}

Selain itu, untuk mengetahui keefektifan dari metode yang digunakan maka penelitian ini juga menguji hipotesis menggunakan Uji T Berpasangan. Namun sebelum melakukan uji hipotesis harus melakukan uji Normalitas terlebih dahulu. Uji Normalitas digunakan untuk mengetahui data dalam penelitian ini terdistribusi normal atau tidak. Pengujian normalitas tergantung pada jumlah respondennya. Jika jumlah respoden melebihi 50 sampel maka menggunakan Kolmogorov Smirnov. Namun, jika sampel berjumlah kurang dari 50 sampel maka menggunakan Shapiro Wilk. Sampel yang digunakan dalam penelitian ini kurang dari 50 siswa sehingga menggunakan Shapiro Wilk. Apabila nilai $p$ value $>0,05$ dapat disimpulkan bahwa data terdistribusi normal.

Jika data terdistribusi normal maka uji hipotesis menggunakan Uji T Berpasangan. Uji T berpasangan digunakan untuk membuktikan uji hipotesis. Pengujian juga dapat membandingkan nilai $t_{\text {hitung dan }} t_{\text {tabel }}$ yang didasarkan pada taraf signifikan tertentu yaitu $\alpha=0,05$. Jika nilai $t_{\text {hitung }}>t_{\text {tabel }}$ maka terdapat perbedaan yang signifikan antara model problem based learning berbantuan moodle terhadap motivasi dan hasil belajar kognitif siswa. Namun sebaliknya, jika nilai $t_{\text {hitung }}<t_{\text {tabel }}$ maka tidak terdapat perbedaan yang signifikan antara model problem based learning berbantuan moodle terhadap motivasi dan hasil belajar kognitif siswa. Namun, jika data terdistribusi tidak normal maka uji hipotesis menggunakan uji Wilcoxon.

Pada penelitian ini menggunakan Wilcoxon signed Rank Test untuk menguji hipotesis yang terdistribusi tidak normal. Wilcoxon signed Rank Test adalah metode statistik non parametik yang digunakan untuk membandingkan perbedaan dua media, fungsinya sama seperti dengan uji $\mathrm{T}$ berpasangan. Uji ini juga menggunakan signifikan tertentu yaitu 0,05. Jika $z_{\text {hitung }}>z_{\text {tabel }}$ maka terdapat perbedaan yang signifikan antara model problem based learning berbantuan moodle terhadap motivasi dan hasil belajar kognitif siswa. Namun sebaliknya, jika nilai $z_{\text {hitung }}<z_{\text {tabel }}$ maka tidak terdapat perbedaan yang signifikan antara model problem based learning berbantuan moodle terhadap motivasi dan hasil belajar kognitif siswa.

\section{HASIL DAN PEMBAHASAN}

HASIL

1. Motivasi Belajar Siswa

Motivasi belajar siswa diukur dengan memberikan angket motivasi kepada siswa setelah penerapan model problem based learning berbantuan moodle angket yang diberikan berjumlah 15 butir pernyataan yang disajikan pada Tabel 4 .

Tabel 4. Presentase Motivasi Belajar Siswa

\begin{tabular}{cccc}
\hline $\begin{array}{c}\text { Tingkat } \\
\text { Keberhasilan }\end{array}$ & Keterangan & Frekuensi & Presentase \\
\hline $0-39$ & SangatRendah & 1 & $3 \%$ \\
\hline $40-54$ & Rendah & 12 & $33 \%$ \\
\hline $55-74$ & Cukup & 20 & $56 \%$ \\
\hline $75-89$ & Tinggi & 3 & $8 \%$ \\
\hline $90-100$ & Sangat Tinggi & 0 & $0 \%$ \\
\hline
\end{tabular}


Pengaruh Model Pembelajaran...

Berdasarkan hasil analisis diatas diketahui bahwa dari 36 siswa 1 siswa berada pada kategori sangat rendah, 12 siswa berada pada kategori rendah, 20 siswa berada pada kategori cukup, 3 siswa berada pada kategori tinggi dan 0 siswa berada pada kategori sangat tinggi. dari hasil diatas terlihat bahwa motivasi belajar siswa masih berada kategori cukup.

2. Hasil Belajar Siswa

Hasil belajar siswa diukur dengan menggunakan 15 butir soal pertanyaan yang diberikan sebelum dan setelah pembelajaran yang disajikan pada Tabel 5 .

Tabel 5. Presentase Pre Test Siswa

\begin{tabular}{cccc}
\hline $\begin{array}{c}\text { Tingkat } \\
\text { Keberhasilan }\end{array}$ & Keterangan & Frekuensi & $\begin{array}{c}\text { Presentas } \\
\text { e }\end{array}$ \\
\hline $0-39$ & Sangat Rendah & 3 & $3 \%$ \\
\hline $40-54$ & Rendah & 11 & $33 \%$ \\
\hline $55-74$ & Cukup & 21 & $56 \%$ \\
\hline $75-89$ & Tinggi & 1 & $8 \%$ \\
\hline $90-100$ & Sangat Tinggi & 0 & $0 \%$ \\
\hline
\end{tabular}

Berdasarkan analisis diatas terlihat bahwa dari 36 siswa terdapat 3 siswa berada pada kategori sangat rendah, 11 siswa berada pada kategori rendah, 21 siswa berada pada kategori cukup, 1 berada pada kategori tinggi dan 0 siswa berada pada kategori sangat tinggi. Setelah diterapkan model problem based learning berbantuan moodle yang disajikan pada Tabel 6 .

Tabel 6. Presentase Post Test Siswa

\begin{tabular}{cccc}
\hline $\begin{array}{c}\text { Tingkat } \\
\text { Keberhasilan }\end{array}$ & Keterangan & Frekuensi & Presentase \\
\hline $0-39$ & Sangat Rendah & 0 & $0 \%$ \\
\hline $40-54$ & Rendah & 0 & $0 \%$ \\
\hline $55-74$ & Cukup & 12 & $33 \%$ \\
\hline $75-89$ & Tinggi & 23 & $64 \%$ \\
\hline $90-100$ & Sangat Tinggi & 1 & $3 \%$ \\
\hline
\end{tabular}

Berdasarkan analisis diatas dapat diketahui bahwa dari 36 siswa terdapat 0 siswa berada pada kategori sangat rendah, 0 siswa berada pada kategori rendah, 12 siswa berada pada kategori cukup, 23 siswa berada pada kategori tinggi dan 1 siswa berada pada kategori sangat tinggi. Setelah diketahui hasil analisis dari pre test dan post test masing-masing siswa, selanjutnya akan diukur peningkatan hasil belajar kognitif siswa dengan N-Gain yang disajikan pada Tabel 7.

Tabel 7. N-Gain Hasil Belajar Kognitif Siswa

\begin{tabular}{clcc}
\hline Rentang & Kategori & Frekuensi & Presentase \\
\hline $\mathrm{N}-\mathrm{G} \geq 0.7$ & Tinggi & 7 & $19 \%$ \\
\hline $0.3 \leq \mathrm{N}-\mathrm{G} \leq 0.7$ & Sedang & 21 & $58 \%$ \\
\hline $\mathrm{N}-\mathrm{G}<0.3$ & Rendah & 8 & $22 \%$ \\
\hline
\end{tabular}

Berdasarkan data diatas diketahui bahwa dari 36 siswa yang memiliki peningkatan dengan kategori rendah sebanyak 8 siswa, peningkatan sedang sebanyak 15 siswa dan 7 siswa dengan peningkatan tinggi. Selain itu diukur pula N-Gain rata-rata dari keseluruhan siswa yang ada dikelas, yaitu didapatkan hasil berikut.

Tabel 8. Rata-rata N-Gain Hasil Belajar Siswa

\begin{tabular}{ccccc} 
& Pre Test & Post Test & N-Gain & Kategori \\
\hline $\begin{array}{c}\text { Hasil Belajar } \\
\text { Kognitif }\end{array}$ & 56,71 & 78,5 & 0,503 & Sedang \\
\hline
\end{tabular}


Pengaruh Model Pembelajaran...

Berdasarkan data diatas dapat diketahui bahwa peningkatan hasil belajar kognitif siswa berada pada kategori sedang dengan nilai 0,503. Selain itu, berikut akan dipaparkan hasil uji hipotesis. Namun sebelum itu dilakukan uji normalitas terlebih dahulu. Hal ini dilakukan agar mengetahui normalitas data. Berikut uji normalitas hasil belajar kognitif siswa.

Tabel 8. Uji Normlitas Hasil Belajar Kognitif Siswa

\begin{tabular}{lcccccc}
\hline & \multicolumn{3}{c}{ Kolmogorov-Smirnov $^{\text {a }}$} & \multicolumn{3}{c}{ Shapiro-Wilk } \\
\cline { 2 - 8 } Pre Test & Statistic & df & Sig. & Statistic & Df & Sig. \\
\hline Post Test &, 207 & 36 &, 000 &, 928 & 36 &, 021 \\
\hline
\end{tabular}

Berdasarkan data diatas dapat dikethaui bahwa nilai signifikansi hasil belajar siswa memiliki nilai dibawah 0,05 . Hal ini menunjukkan bahwa data terdistribusi tidak normal, artinya pengujian hipotesis menggunakan Wilcoxon Signed Rank Test. Berikut adalah hasil uji Wilcoxon Signed Rank Test.

Tabel 9. Uji Wilcoxon Hasil Belajar Kognitif Siswa

\begin{tabular}{lccc}
\hline & z-hitung & z-tabel & Sig. \\
\hline Pre-test & 5,094 & 2,892 & 0,000 \\
\hline Post Test & & 2,000 \\
\hline
\end{tabular}

Berdasarkan data diatas dapat diketahui bahwa nilai signifikansi sebesar 0,000 yang artinya memiliki nilai kurang dari 0,05. Sedangkan jika dibandingkan antara nilai Ztabel dan Zhitung, dapat dilihat hasil dari Zhitung sebesar 5,094 sedangkan Ztabel sebesar 2,892. Jika $z_{\text {hitung }}>z_{\text {tabel }}$, maka $\mathrm{H}_{0}$ di tolak, artinya terdapat perbedaan antara hasil belajar pre test dan post test.

\section{PEMBAHASAN}

Pada penelitian ini penggunaan model problem based learning dibantu dengan moodle agar proses kegiatan belajar mengajar dapat meningkatkan motivasi dan hasil belajar kognitif siswa. Moodle digunakan selama proses penerapan model problem based learning yaitu melakukan eksperimen secara online. Selain itu, moodle juga digunakan diluar jam sekolah yaitu siswa diberikan tugas dan mengumpulkan tugas secara online.

Pada pertemuan pertama, siswa masih belum bisa menggunakan moodle secara keseluruhan karena masih ada siswa yang belum mengumpulkan e-mail. Ketika seluruh siswa telah mengumpulkan e-mail, peneliti kemudian membuatkan akun untuk siswa agar bisa digunakan. Pada awalnya siswa masih belum terbiasa dengan moodle yang digunakan, hal ini menyebabkan situasi kelas menjadi sangat tidak kondusif sehingga kegiatan belajar mengajar menjadi tidak efektif.

Pertemuan kedua, siswa mulai diberikan tugas yang dapat di akses pada moodle yaitu dengan mendownload tugas kemudian mengupload ke moodle dalam kurun waktu 6 hari. Selain masih kesulitan dalam menggunakan moodle, pertemuan ini pula siswa tampak kesulitan dalam memecahkan masalah sebagai penerapan model problem based learning, salah satunya ialah kesulitan dalam merumuskan masalah dan membuat hipotesis. Oleh karena itu pendidik memiliki andil sebagai fasilitator siswa dalam membantu memecahkan masalah yang diberikan. Pertemuan selanjutnya, siswa mulai bisa mengikuti proses pembelajaran dengan baik namun tetap saja masih perlu diarahkan. Berikut ini akan dipaparkan mengenai motivasi dan hasil belajar kognitif siswa.

1. Motivasi belajar siswa

Hasil motivasi belajar siswa kelas XI IPA 5 diketahui dari 36 siswa terdapat 1 siswa yang

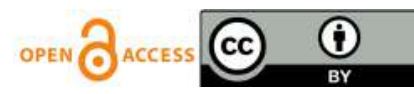


Pengaruh Model Pembelajaran...

memiliki motivasi belajar sangat rendah, 12 siswa kategori rendah, 20 siswa kategori cukup, 3 siswa kategori tinggi dan 0 siswa kategori sangat tinggi. Berdasarkan data tersebut dapat diketahui bahwa motivasi siswa dalam pembelajaran masih tergolong cukup. Hal ini menandakan bahwa masih perlunya perbaikan dalam kegiatan belajar mengajar agar motivasi siswa dapat meningkat. Saat pembelajaran siswa kesulitan mengikuti langkah-langkah dalam menerapkan problem based learning. Siswa kesulitan dalam memecahkan masalah yang diberikan. Hal ini disebabkan siswa tidak menguasai materi yang disampaikan. Seperti penelitian yang telah dilakukan oleh Astuti (2017) membuktikan bahwa siswa dapat memecahkan masalah jika siswa memahami materi yang disampaikan. Menurut Arend (Astuti, 2017), problem based learning tidak melihat yang siswa lakukan namun dari apa yang siswa pikirkan.

Selain itu, siswa juga tidak tertarik pada penggunaan moodle dalam kegiatan pembelajaran. Siswa merasa penggunaan moodle sangat menghabiskan paket data. Siswa juga kesulitan mengirimkan tugas ke moodle dalam bentuk gambar karena harus mengirimkannya berulangulang. Hal ini dirasakan oleh beberapa siswa. Namun, siswa lainnya merasa moodle membuat pembelajaran menjadi tidak membosankan walaupun harus dengan merasakan beberapa kendala sebelumnya. Hal inilah yang membuat motivasi belajar siswa dominan pada kategori cukup. Oleh karena itu penerapan moodle dalam pembelajaran perlu dilakukan dalam jangka waktu panjang agar siswa dapat terbiasa dengan e-learning moodle.

2. Hasil belajar kognitif siswa

Untuk mengetahui peningkatan hasil belajar siswa, maka peneliti memberikan soal tes sebelum dan setelah pembelajaran. Sebelum pembelajaran dimulai siswa mengerjakan soal tes sebanyak 15 soal. Berikut hasil dari pre test siswa ialah dari 36 siswa terdapat 3 siswa berkategori sangat rendah, 11 siswa berkategori rendah, 21 siswa berkategori cukup, 1 orang berkategori tinggi dan 0 siswa berkategori sangat tinggi. Hasil ini masih mendominasi kategori cukup. Setelah penerapan model problem based learning berbantuan moodle maka siswa diuji dengan soal yang sama untuk mengetahui peningkatan hasil belajar siswa. Hasil dari post test siswa ialah dari 36 siswa terdapat 0 siswa berkategori sangat rendah, 0 siswa berkategori rendah, 12 siwa berkategori cukup, 23 siswa berkategori tinggi dan 1 siswa berkategori sangat tinggi. Post test memperlihatkan bahwa nilai siswa yang mendominasi ialah kategori tinggi. Namun, untuk mengetahui peningkatan hasil belajar kognitif masing-masing siswa maka diukur menggunakan N-Gain dengan hasil sebagai berikut: dari 36 siswa terdapat 7 siswa dengan peningkatan hasil belajar dengan kategori tinggi, 21 siswa berkategori sedang dan 8 siswa berkategori rendah. Jika dirata-ratakan peningkatan seluruh siswa maka didapatkan hasil $\mathrm{N}$ Gain sebesar 0,503 dengan kategori sedang. Hal ini membuktikan bahwa peningkatan hasil belajar kognitf siswa masih dalam kategori sedang. Hasil uji hipotesis yang diukur menggunakan Uji Wilcoxon diketahui bahwa $z$ tabel sebesar 5,094 dan z hitung sebesar 2,892 artinya z_hitung $>$ z_tabel sehingga dapat disimpulkan bahwa terdapat perbedaan antara nilai pre test dan nilai post test.

Berdasarkan data diatas, hasil belajar siswa masih berada pada kategori sedang sehingga masih perlu perbaikan dalam kegiatan belajar mengajar. Terdapat beberapa kendala dalam proses pembelajaran. Jika ditinjau dari nilai siswa terdapat peningkatan sebesar $61 \%$ pada kategori tinggi. Namun setelah dihitung menggunakan N-Gain, bahwa siswa mengalami peningkatan hasil belajar kognitif dengan kategori sedang. Hal ini disebabkan oleh beberapa hal yaitu kondisi kelas yang tidak kondusif saat kegiatan belajar mengajar. Peserta didik merasa bosan dalam pembelajaran sehingga mencari kesibukan sendiri dengan mengobrol dengan temannya. Oleh karena itu, perlunya pengkondisian kelas terlebih dahulu baru kemudian pendidik dapat mengajarkan materi. Selain itu, waktu belajar dalam kegiatan belajar mengajar tidak memadai sehingga penyampaian materi menjadi

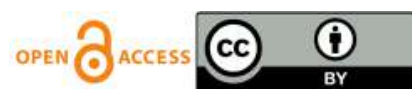


Pengaruh Model Pembelajaran...

tidak maksimal dan terkesan terburu-buru. Kondisi ini seharusnya bisa diselesaikan dengan penggunaan e-learning moodle. Siswa bisa mengakses materi kapan dan dimana saja. Namun, elearning ini tidak dimanfaatkan oleh siswa dengan baik sehingga e-learning moodle tidak membantu siswa dalam pembelajaran. Oleh karena itu, sebaiknya sebelum memulai materi yang akan disampaikan peserta didik diberi tugas untu meresume materi yang akan dipelajari selanjutnya agar mengefektifkan penggunaan waktu dalam kegiatan belajar mengajar.

Motivasi menjadi hal yang sangat penting dalam diri individu. Motivasi yang besar dapat mendorong diri individu dalam mencapai tujuannya. Tanpa adanya tujuan seseorang akan tidak memiliki semangat dalam mencapai tujuan dan akan membuat seseorang akan kesulitan mencapai tujuannya. Menurut Sadirman (2011) motivasi terbagi menjadi dua yaitu motivasi instrinsik dan ekstrinsik. Motivasi intrinsik adalah motivasi yang ada didalam diri individu sedangkan motivasi ekstrinsik merupakan dorongan dari luar diri individu. Penerapan model pembelajaran dalam kegiatan belajar mengajar merupakan cara untuk meningkatkan motivasi secara eksternal. Ketika diberi dorongan dari luar diri individu namun tidak mempengaruhi motivasi dalam diri siswa tersebut maka hal ini tidak akan memiliki pengaruh dalam diri individu. Selain itu, adanya motivasi belajar siswa yang tinggi juga mempengaruhi hasil belajar kognitif siswa menjadi lebih meningkat. Hal ini terbukti dari penelitian yang dilakukan pada siswa kelas XI IPA 5. Motivasi belajar siswa yang tergolong cukup mempengaruhi hasil belajar siswa yang masih tergolong sedang.

\section{PENUTUP}

Berdasarkan hasil penelitian dan pembahasan, maka dapat ditarik kesimpulan bahwa penggunaan model problem based learning berbantuan moodle cukup membantu dalam meningkatkan motivasi dan hasil belajar kognitif siswa kelas XI IPA 5 di SMAN 5 Samarinda. Hal ini terlihat dari hasil angket yang telah diberikan dengan analisis dari 36 siswa 3\% berada pada kategori sangat rendah, $33 \%$ pada kategori rendah, $56 \%$ pada kategori cukup, $8 \%$ pada kategori tinggi dan $0 \%$ pada kategori sangat tinggi dengan motivasi dominan pada kategori sedang. Sedangkan peningkatan hasil belajar siswa setelah dianalisis dari 36 siswa terdapat 7 siswa yang mengalami peningkatan tinggi, 21 siswa pada kategori sedang dan 8 siswa mengalami peningkatan hasil belajar kognitif yang rendah. Jiika ditinjau dari hasil N-Gain rata-rata siswa yaitu sebesar 0,503 yang berada pada kategori sedang.

Berdasarkan temuan-temuan yang diperoleh selama penelitian, maka peneliti menyarankan dalam menggunakan model problem based learning agar dapat membimbing siswa dengan baik. Hal ini dilakukan agar siswa mudah dalam memecahkan masalah yang diberikan. Selain itu, disarakan untuk melakukan penelitian lebih lanjut terkait penggunaan model problem based learning berbantuan moodle di beberapa sekolah agar mendapatkan hasil penelitian yang lebih akurat.

\section{DAFTAR PUSTAKA}

Abadi, B. C (2017). Penerapan Self Direckted Learning Berbasis Moodle Untuk Meningkatkan Hasil Belajar Siswa Kelas XI Teknik Komputer Jaringan. Jurnal IT-EDU . 02 (01), 163

Arikunto, S. (2007). Dasar-dasar Evaluasi Pendidikan . Jakarta . Bumi Aksara

Astuti, P, Suryani, Wilujeng, I., (2017). Keefektifan Pembelajaran Fisika Model Problem Based Learning (PBL) Ditinjau Dari Penguasaan Materi, Keterampilan Memecahkan Masalah, Dan Sikap Kerja Sama Peserta Didik SMA. Skripsi, tidak dipublikasikan. Universitas Negeri Yogyakarta.

Maghfiroh, L. Subchan, W. \& Iqbal, M.. (2016). Aplikasi Problem Based Learning berbantuan Moodle 
Pengaruh Model Pembelajaran...

untuk Meningkatkan Self Regulated Learning Siswa dan Meningkatkan Hasil Belajar Siswa pada Materi Ekologi Kelas XIPA 2. Jurnal Edukasi. 3 (1), 6

Istiningtyas, R. D. (2018). Penerapan Model Problem Based Learning untuk Meningkatkan Motivasi dan Prestasi Belajar Ekonomi Siswa Kelas XI IPA 4 SMA Negeri 1 Sedaya Tahun AJARAN 2017/2018. Skripsi, tidak dipublikasikan . Universitas Negeri Yogyakarta.

Hamalik, O. (2001). Proses Balajar dan Mengajar. Jakarta: PT. Bumi Aksara.

Komara, E. (2014). Belajar dan Pembelajaran Interaktif. Bandung: Refika Aditama.

Manggabarani, F., Sugiarti , \& Masri, M. (2016). Pengaruh Model Pembelajaran Blended Learning Terhadap Motivasi dan Hasil Belajar Siswa Kelas X SMA Negeri 1 Pitumpanua Kab.Wajo. Skripsi, tidak dipublikasikan Makasar: Universitas Negeri Makasar.

Muazizah, N. (2016). Keefektifan Penggunaan E-Learning Berbasis Moodle dengan Pendekatan Guinded Inquiry untuk Meningkatkan Hasil Belajar Materi Hidrokarbon Kelas XI. Skripsi, tidak dipublikasikan. Universitas Mulawarman

Novianto, A. (2016). Pengaruh Penerapan Media Pembelajaran Moodle Terhadap Motivasi Belajar Siswa XII TKJB SMKN 2 Surakarta pada Kompetensi Mengadiministrasikan Server Jaringan Tahun Pelajaran 2015/2016. Dutacom,11 (1), 69.

Priansyah, D. J. (2015). Manajemen Peserta Didik dan Model Pembelajaran; Cerdas, Kreatif dan Inovatif. Bandung: Alfabeta.

Rahmawati, N. N. (2018). Penerapan Flipped Classroom pada Materi Hidrolisis Garam untuk Meningkatan Self-Regulated Learning Siswa Kelas XI MIPA 1 SMA Negeri 2 Samarinda Tahun Ajaran 2017/2018. Skripsi, tidak dipublikasikan. Universitas Mulawarman.

Rusman. (2011). Model-model Pembelajaran Mengembangkan Profesionalisme Guru. Jakarta: PT. Rajagrafindo Persada

Sadirman. (2011). Interaksi dan Motivasi Belajar Mengajar. Jakarta: Rajawali Pers.

Sugiono. (2015). Metode Penelitian Pendidikan. Bandung: Alfabeta.

Sukri, A. \& Purwanti, E. (2019). Meningkatkan Hasil Belajar Siswa Melalui Brain Gym. Jurnal Edukasi Matematika dan Sains . 1(1), 50

Susanti, L. (2014). Pengaruh Metode Problem Based Learning (PBL) Terhadap Motivasi Belajar dan Hasil Belajar Siswa Kelas VIII SMP Negeri 1 Pamona Utara Sulawesi Tengah. Skrispi, tidak dipublikasikan . Universitas Kristen Satya Wacana

Sutikno, S. (2013). Belajar dan Pembelajaran. Lombok: Holistica 